\title{
降雨のインパクトによる高濁度水発生と細粒 土砂輸送に関する現地観測とモデル化 \\ FIELD EXPERIMENT AND MODELING OF PRODUCTION OF SUSPENDED SEDIMENT DUE TO IMPACT OF RAINFALL AND ITS TRANSPORT
}

\author{
石田哲也 1 - 中山恵介 ${ }^{2} \cdot 丸$ 谷靖幸 3 - 大森未音 4 - 菅原庸平 3 ・ \\ Ayinuer ABULIZI ${ }^{5} \cdot$ 上野義勝 \\ Tetsuya ISHIDA, Keisuke NAKAYAMA, Yasuyuki MARUYA, Mio OMORI, \\ Yohei SUGAWARA, Ayinuer ABULIZI and Yoshikatsu UENO
}

\begin{abstract}
1正会員 国土交通省 北陸地方整備局 信濃川河川事務所 ( $\bar{T} 940-0098$ 新潟県長岡市信濃1丁目5 番30号)
2正会員 工博 北見工業大学教授 工学部社会環境工学科 ( $\bar{\top}$ 090-8507 北海道北見市公園町165番地)

3学生会員 北見工業大学大学院 土木開発工学専攻 (广 090-8507 北海道北見市公園町 165 番地)

4正会員 国土交通省 北海道開発局 網走開発建設部 ( $\bar{\top} 093-8544$ 北海道網走市新町 $2 丁$ 目6番1号)

5 非会員 北見工業大学大学院 寒冷地・環境・エネルギー工学専攻 ( $\overline{0} 090-8507$ 北海道北見市公園町165 番地)

5 非会員＼cjkstart北海道オホーツク総合振興局東部森林室 ( $\bar{\top} 090-0018$ 北海道北見市青葉町2番10号)
\end{abstract}

\begin{abstract}
In the previous studies, high turbidity is revealed to occur in Tokoro River and to affect social economical and environmental activity in Okhotsk area. Also, it is demonstrated that turbidity from fields is one of the most influential factors on high turbidity in Tokoro River. However, it is not clarified how high turbidity is provided from fields and forests areas. Therefore, this study attempted to understand the mechanisms of the occurrence of high turbidity and the role of fields and forests areas on the occurrence of high turbidity. In 2 hectors field and forest areas, SS concentration due to the impact of rainfall is investigated in 2009, which reveals that SS concentration is associated with rainfall intensity by using exponential function. Also, it is found that SS concentration in field tends to increase with rainfall intensity more rapidly than forest areas. The proposed equation for evaluating SS concentration is confirmed to have high applicability by using distributed hydrological model.
\end{abstract}

Key Words : High turbidty, Distributed hydrological model, Suspended solid

\section{1.はじめに}

北海道才ホーツク地方を流れる常呂川は網走管内最大 の流域面積を誇る河川であり，流域内に管内最大の人口 (13万人)を持つだけでなく，鮭やマスの遡上, 上流域で の貴重な生物の生息力認められており，環境面から考え ても重要な河川であると言える.さらに，陸域における 栄養を沿岸域に与える役割も持ち, 河口部周辺ではホタ テの養殖力盛んである . 市民の生活にも大きな影響を与 えており，周辺市民の水源としての役割も持つ．

そのような重要な役割を持つ一方, 平成13年9月の洪 水時における河口からの濁水・土砂流出によると考えら れている大量のホタテの整死, 平成19年6月の常呂川第
一頭首工口周辺における濁水の取水による北見市の水道 断水など, 社会的に大きなダメージも与える可能性が大 きい河川であると言える .

上述の事故は，濁水・土砂によって発生した問題であ るが, 水質環境の面からみて, 鮭が逆上する河川である にもかかわらず, 大腸菌群数が大きく, 決して水質環境 がよいとは言えない河川であり, 改善すべき点か存在す る. 弚れらの問題を解決するためには, 河道内における 濁水・土砂・水質環境の流動を把握し再現するだけでは， 十分な対策を講じることか困難であり，弚れらの発生源 である，流域全体を対象とした対策を検討・提案する必 要があると言える .

つまり，陸域から沿岸域までの土砂，水質環境を把握 し，陸域の沿岸域へのインパクト，および沿岸域からの 


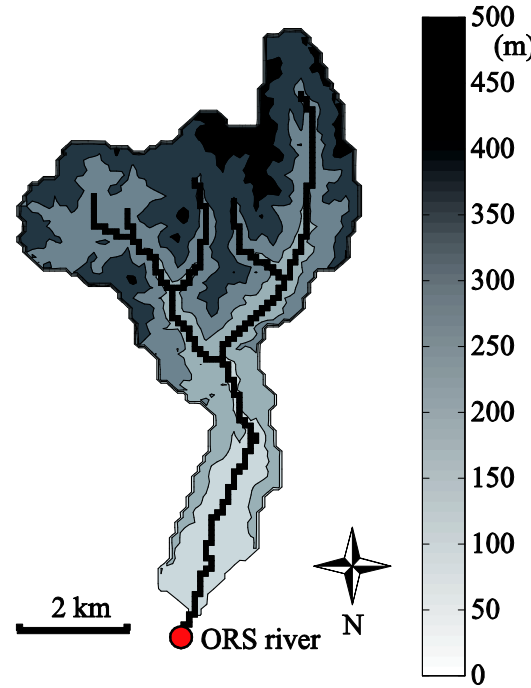

図-1 研究対象流域(オロムシ川)の河道と標高の関係( 図中の 流域下流端におけるOORS_ri ver は水位, 濁度の観測位 置を示す)

陸域へのフィードバッグを理解する必要があると言え $ろ^{2)}$. 特に寒冷地域に位置する常呂川では, 融雪期にお ける細粒土砂の発生, 弚れによる生態系への影響が大き いと考えられる . 北海道における事例を主として挙げた が, 関連する問題として , 沖縄周辺での細粒分土砂の沿 岸域へ流出による問題力存在する. 細粒分の土砂流出が， 珊瑚を壊滅的な状態に追い込んている問題でありり尚)， 細粒分の土砂輸送に関わる問題は至急, 解決されなくて はならない課題であると言える .

石田ら $(2010)^{5)}$ では, 融雪期の高濁度水発生条件とし て , 流域の採泥による粒度分布結果から $64 \mu \mathrm{m}$ 以下の細 粒土砂か流域全域に分布しており, 光れらか下流端に運 搬されている可能性を示し，融雪期による高濁度水の観 測結果を基に , 流域の斜面から一樣に発生濁度を与える ことで, 流域下流端での濁度の観測結果を精度よく再現 できることを示した . また , Ishidaら (2010) ${ }^{6}$ では, 流域 内の表層土猿の種類に着目し，採泥した表層土壌から化 学組成分析を行い, 類似性の評価により流域内のどの区 域から流域下流端に細粒土砂がどの程度の割合で流出し ているのかを評価し，表層土壌の違いにより細粒土砂の 流出への寄与率が違うことを示した .

本研究ては, 流域における総合的な土砂輸送の把握， 水質環境の維持・改善を目的とし，まずは常呂川で最も 大きな問題であると考えられている高濁度水の発生要因 の解明を目的として研究を行っている.これまでの高濁 度水発生による災害を考慮して研究対象とした時期は， 高濁度水の発生を確認出来た2009年 , 2010年の観測結果 (融雪期を除く)である. 兴の高濁度水の発生要因を検討 するため，流域の土地利用区分によって細粒土砂の生産 特性が違うことを考慮することを目的に畑地と森林地の 2箇所において高濁度発生の特徵を観測により解明し， 分布型流出モデルを適用した .

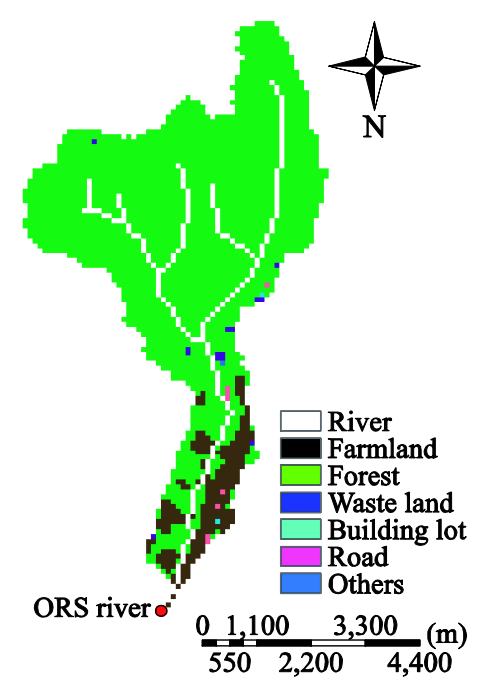

図-2 研究対象流域 オロムシ川)の土地利用区分( 図中の流域 下流端におけるOORS_ri verは水位, 濁度の観測位置を 示す)

\section{2 . 降雨による高濁度水の発生}

本研究の目的が, 細粒分土砂の発生要因解明であるこ とから，土地利用の状態，表層土壤の状態などを詳細に 検討し，解析を行う必要がある. 常呂川流域では, 弚れ らの空間的な情報が, 数km単位で分布している. 弚こ で本研究では, 詳細な表層土壌の土地利用などの空間分 を考慮するため, 流域面積 $29.3 \mathrm{~km}^{2}$, 流路延長 $9.7 \mathrm{~km}$, 平 均河床勾配 $1 / 43$ である, 常呂川流域の小河川であるオ口 ムシ川流域を研究対象とした(図-1).

オロムシ川流域の土地利用区分は，森林 $80.7 \%$, 烟地 15.7\%であり．流域の土壤構成は，粗粒残積性の未熟土 壤 $59.6 \%$ と黑ぼく土壤(a) $32.6 \%$ が流域の大半を占めてい $\tau^{5) 6}$, 大半か森林 (上流域) と畑地(下流域) て構成されて いる( 図- 2) . オロムシ川における細粒土砂の粒径は ,

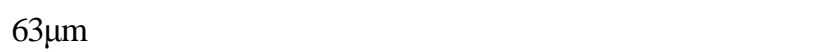
可能性が示されている5),6.

2009年9月9日から 11 月 25 日，2010年6月1日から7月 20 日までにオロムシ川下流端 (図-1，2)で計測した水位と SS濃度を示す(図-3) . 谷の際, 過去の調査て作成された 水位流量曲線を用い，流量を計算した。また，SS濃度は， 現地て採泥した土砂を用いて室内実験によってキャリブ レーションを行い, 計測器の観測結果 $(\mathrm{ppm})$ とSS濃度 $(\mathrm{mg} / \mathrm{L})$ の関係式により計算された $\mathrm{SS}$ 濃度 $(\mathrm{mg} / \mathrm{L})$ である . オロムシ川における濁度水の発生・流出は，2009年か ら2010年の2年間の観測結果により，降雨によく反応し て発生していた(図-3) . 2年間の観測期間中で2009年10 月9日には，SS濃度で15,000mg/L，2010年7月8日にはSS 濃度で56,000mg/Lもの高濁度を観測した .このように， オロムシ川ではたびたび10,000mg/Lを超えるような超高 

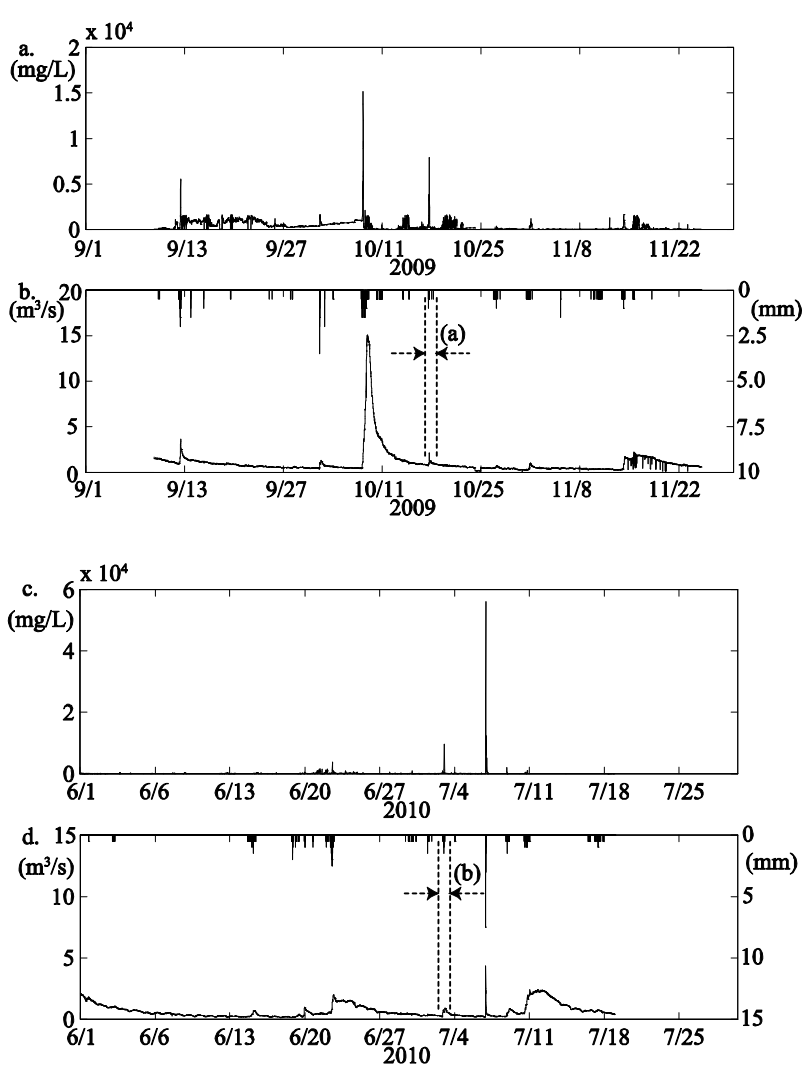

图-3 降雨(アメダス観測点: 北見観測所)，流量と濁度の関係 ( $a ， b: 2009$ 年，c，d：2010年の観測結果)，(( a)，(b) は計算対象区間を示す)

濁度を発生させる特徵があることか明らかになった(図3) .

\section{3. 森林と畑地における発生濁度の推定}

オロムシ川は流域の大半を森林と畑地か沾めているこ とから，森林と畑地における濁度の発生特性について明 らかにするため, 常呂川流域内の森林地と畑地において 現地て観測を実施した . 観測を行った森林地の流域面積

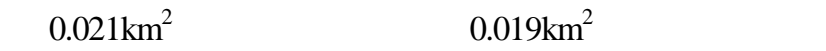
流端への流出時間はほとんど差がない小流域である，観 測方法は，流域下流端に三角堰を設置し，三角堰( 図-4) に流入してくる濁度と水位を計測した(写真-1)．濁度は， オロムシ川下流端での観測結果と同樣に室内実験によっ て得られたキャリブレーション結果を用いてSS濃度を計 算した . 流出量は三角堰の公式を用いて計算した . 森林 地と畑地の観測期間は光れ光れ，森林地で2010年2月16 日12時30分から7月8日11時30分，畑地で2010年4月9日10 時50分から7月 8 日10時20分までである．また，森林地の 観測結果は, データロガの電池の電力が不足したことに より，5月26日14時から6月3日17時まで次測である .

森林地と畑地の観測サイトで把握できた状況として， 畑地では土砂流出が活発で三角堰が土砂で堆積する現象

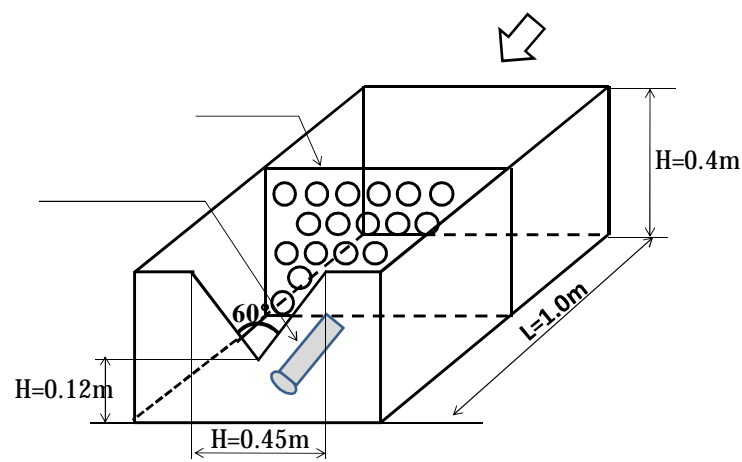

図-4 森林地と畑地に設置した三角堰( $60^{\circ}$ 堰)の模式図

か確認されており(写真- 2)，森林地では三角堰内に堆積 している土砂が腐葉土を中心として非常に細かく, 三角 堰の水か活しされると同時に巻上りか発生する現象力確認 された . 特に畑地は森林地と比較して, 細粒土砂の生 産・流出が活発で, 流出に伴う土砂流出により三角堰に 土砂か堆積した後は, 三角堰から堆積土砂を撤去しない 限りSS濃度は観測されない状況が何度も確認された(写 真-2) . 森林地では, 畑地のような土砂堆積による欠測 はなかった . 光のため, 降雨によって生産・流出する細 粒土砂の特性を把握するため，森林地と畑地の観測結果 を比較する際に上述のような影響を考慮し，森林地で6 降雨パターン, 畑地で8降雨パターンの観測データを抽 出した。

抽出された森林地と畑地の観測期間に計測されたSS濃 度とアメダス観測点 (北見観測所) における一連降雨期間 中( 降雨観測の前後24時間の無効雨か観測されている期 間を1降雨パターンとした)の1時間あたりの降雨ピーク と炎の同時刻におけるSS濃度を比較したところ，降雨 ピークとSS濃度のピークがほぼ一致していた . 森林地の 降雨ピークとSS濃度の関係は, 降雨ピークが5mm程度 までSS濃度は増加傾向にあり，弚れ以降，ばらつきはあ るものの降雨ピークカ増加してもSS濃度の増加は小さく なり，降雨ピークの違いによるSS濃度の大きな差は見ら れなかった(表-1, 図-5). 同樣に, 烟地の降雨ピークと $\mathrm{SS}$ 濃度の関係は，降雨ピークが2mm程度までSS濃度は 急激な増加傾向にあり，乥れ以降，ばらつきはあるもの の降雨ピークの違いによるSS濃度の大きな差は見られな かった .一方で, 森林地と畑地のSS濃度を比較すると， 流域面積は同じであるが，森林地より畑地の方が同じ降 雨ピークに対し, SS濃度は高い傾向にあった(表-1, 図5) . 森林地と畑地て観測されたSS濃度の増加範囲におけ る降雨ピークとSS濃度の違いは, 森林地では樹木等によ る降雨の遮断効果か湿著であり, 烟地では作物が育つま では裸地て降雨の遮断効果がくく直接降雨を受けること が原因と考えられる .これら降雨ピークと炎の同時刻に おけるSS濃度の関係から，降雨が大きくなるとSS濃度 が大きくなり，ある程度の降雨以上になるとSS濃度が一 


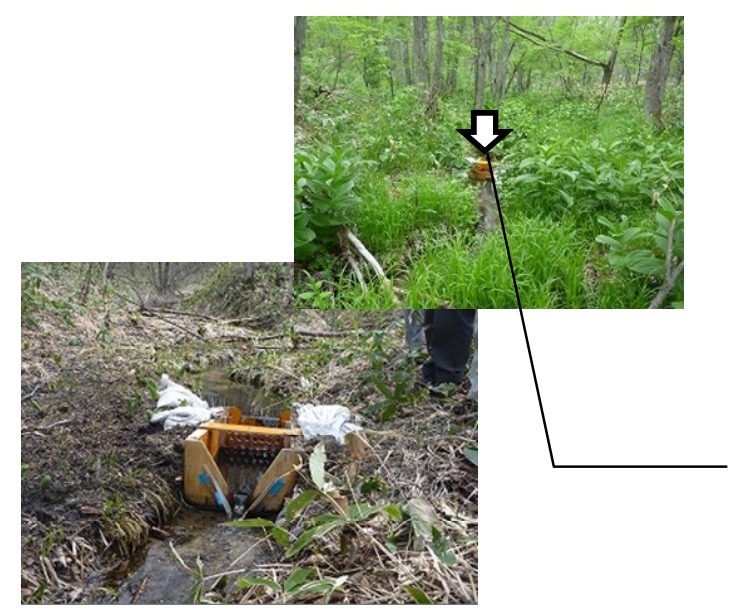

表-1 降雨ピークと炎の同時刻に観測されたSS濃度( 降雨 はアメダス観測点(北見観測所))

\begin{tabular}{|r|c|c|r|r|}
\hline No. & Location & Date & Rainfall $(\mathrm{mm})$ & SS (mg/L) \\
\hline 1 & Forest & $2010 / 06 / 2410: 00$ & 6.5 & 14,053 \\
\hline 2 & Forest & $2010 / 06 / 2411: 00$ & 2.5 & 11,598 \\
\hline 3 & Forest & $2010 / 06 / 2413: 00$ & 1.0 & 3,337 \\
\hline 4 & Forest & $2010 / 07 / 0419: 00$ & 1.5 & 3,043 \\
\hline 5 & Forest & $2010 / 07 / 0815: 00$ & 10.5 & 21,448 \\
\hline 6 & Forest & $2010 / 07 / 0816: 00$ & 5.0 & 17,954 \\
\hline 7 & Field & $2010 / 04 / 2911: 00$ & 1.0 & 5,794 \\
\hline 8 & Field & $2010 / 04 / 2912: 00$ & 1.0 & 5,135 \\
\hline 9 & Field & $2010 / 04 / 2913: 00$ & 0.5 & 4,289 \\
\hline 10 & Field & $2010 / 06 / 2102: 00$ & 1.5 & 10,739 \\
\hline 11 & Field & $2010 / 06 / 2120: 00$ & 2.5 & 22,070 \\
\hline 12 & Field & $2010 / 06 / 2121: 00$ & 3.0 & 18,815 \\
\hline 13 & Field & $2010 / 06 / 2215: 00$ & 2.0 & 22,534 \\
\hline 14 & Field & $2010 / 07 / 0815: 00$ & 10.5 & 24,264 \\
\hline 15 & Field & $2010 / 07 / 0816: 00$ & 5.0 & 30,729 \\
\hline
\end{tabular}

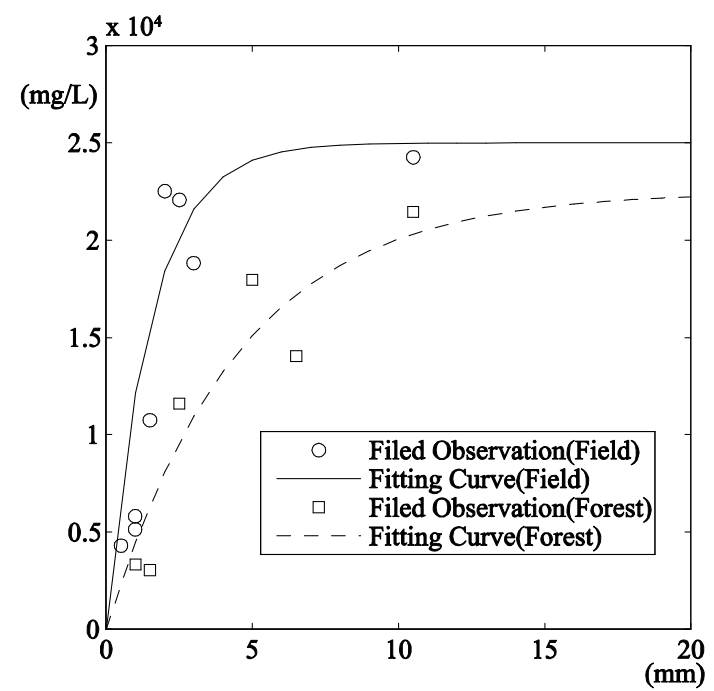

図-5 降雨ピークと光の同時刻に観測されたSS濃度の関係 (降雨はアメダス観測点 (北見観測所) )

$(\mathrm{mm} / \mathrm{hr}) ， \mathrm{R}_{\mathrm{o}}$ : 発生限界雨量 $(\mathrm{mm} / \mathrm{hr})$

畑地と森林値の $\mathrm{SS}_{\max }$ と $\mathrm{R}_{\mathrm{o}}$ はとれ炎れ, 森林地, $\mathrm{SS}_{\text {max }}=22,500 \mathrm{mg} / \mathrm{L}, \mathrm{R}_{\mathrm{o}}=4.5 \mathrm{~mm} / \mathrm{hr}$, 畑地 $\mathrm{SS}_{\max }=$ $25,000 \mathrm{mg} / \mathrm{L}, \mathrm{R}_{\mathrm{o}}=1.5 \mathrm{~mm} / \mathrm{hr}$ である.式(1)によって計 算された降雨とSS濃度の関係は, 観測結果から抽出され た降雨ピークと午の同時刻のSS濃度の関係を十分に表現 していると言える(図-5) . 本モデルを利用して , 森林地 と畑地からの細粒土砂の流出を組み込んだ流出モデルを 構築し , オロムシ川下流端でのSS濃度の再現計算を次章 て試みた。

\section{4 . 分布型流出モデルによる検討}

定になる特性か確認された(図-5)。光こで, 降雨強度と SS濃度の関係を指数関数で近似した(図- 5 , 式(1)).

$$
\mathrm{SS}_{\mathrm{cal}}=\mathrm{SS}_{\max } \cdot\left(1-\exp \left(-\mathrm{R}_{\mathrm{t}} / \mathrm{R}_{\mathrm{o}}\right)\right) \cdot \cdot(1)
$$

ここで, $\mathrm{SS}_{\mathrm{cal}}$ ：流出( 発生) $\mathrm{SS}$ 濃度 $(\mathrm{mg} / \mathrm{L}), \mathrm{SS}_{\mathrm{max}}$ ： 最大流出( 発生) $\mathrm{SS}$ 濃度 $(\mathrm{mg} / \mathrm{L}), \mathrm{R}_{\mathrm{t}}$ : 雨量

オロムシ川下流端, 森林地と畑地の観測結果により， 降雨によって細粒分土砂力泩産され, 高濁度水か発生す ることか推測された . 兴の現象の発生を検証するため, 分布型流出モデルによる再現計算を行った . 
（1）分布型流出モデル

これまでの研究で, 物理過程に基ついた分布型流出モ デルが , 流域からの流出, 細粒分の土砂輸送，および水 質を再現できることが示されている7,,8,9,10) 。光こで本研 究でも, 過去の論文で示されたモデルと同樣な仕組みの モデルを作成し，利用することとした . 表面流にはキネ マティック方程式，氾濫流には浅水流方程式，浸透流に はリチャーズの式に基づく不飽和浸透流方程式 ${ }^{11)}$, 河道 流にはキネマティック方程式を用いた .

計算に用いた流域モデルは100mメッシュ，計算時間 間隔は10秒間隔とし，計算に用いる雨量はアメダス観測 点北見観測所のデータを用いた .

高濁度水の再現計算を行う前に , 流量に関するモデル の再現性の検討を行った . 降雨の入力はアメダス観測点 ( 北見観測所)の観測值を用いて流域内に一樣に与え，再 現計算は，2009年10月18日3時から10月19日16時(図-3(a) 期間) における降雨による流量と2010年7月4日0時から7 月5日11時 (図-3(b)期間) における降雨による流量に対し て行った(図-6). 弚の結果, 細かな変動については検討 の余地があるが , 流量の再現としてはピークの再現も出 来ており，良好な結果を得ることか出来た，今後，より 再現性を向上するための工夫としては, 流域内での空間 分布を考慮した降雨を入力值として与えることにより， より最適な流出計算を行うことが考えられる．

\section{（2）降雨による高濁度水の再現と検討}

前節において，オロムシ川流域における再現性か確認 された分布型流出モデルを用いて, 高濁度水の発生の再 現計算を行った . SS濃度の計算には，流域表面からの細 粒土砂の発生量を与えて, 弚の発生量が全て下流端まで 運搬されるものと仮定し，キネマティック方程式を利用 して表面および可道における輸送を計算した．また，本 研究では，SS濃度か極端に高い場合においても流体の性 質は変化しないものと仮定して計算を行った .

上述のとおり，再現計算には流域表面における細粒土 砂の発生量を与えなくてはならない. 本研究対象とした オロムシ川は, 畑地と森林地に大きく大別されるため , 流域内の土地利用区分を畑地と森林地の2種類に分類し て計算を行った .与えた発生量は，本研究て検討した降 雨ピークとSS濃度の関係からモデル化した式(1)を用い て森林地と畑地の弚れ光れの発生特性を考慮して降雨に 応じてSS濃度を与えて計算を行った(図-7).計算を行っ た期間は , 流出モデルの再現性を検討した期間と同樣で ある。

SS濃度の再現計算結果では, 降雨によって表面流力発 生する場合にSS濃度の反応はよく表現されていた . SS 濃度のピークは概ね再現出来たが, 減衰期やSS濃度かほほ とんど観測されていない場合にも，再現計算ではSS濃度 か計算されている(図-6(a)，図-7(a)).また，再現計算結 果の方か実際に観測された時間より2009年10月18日では
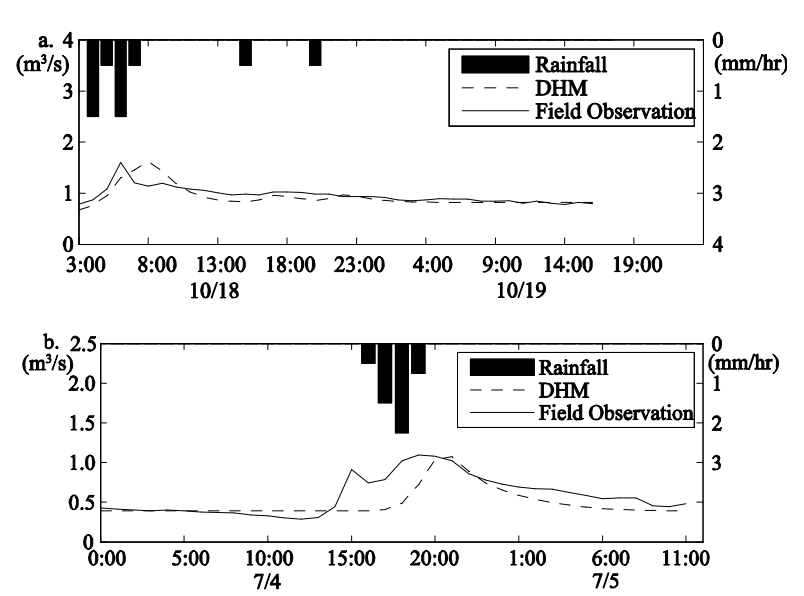

図-6 オロムシ川下流端での流量の再現計算結果

(再現期間 : ( a) 2009/10/18 3: 00-10/19 16: 00

(b) 2010/7/4 0:00-7/4 11: 0 )
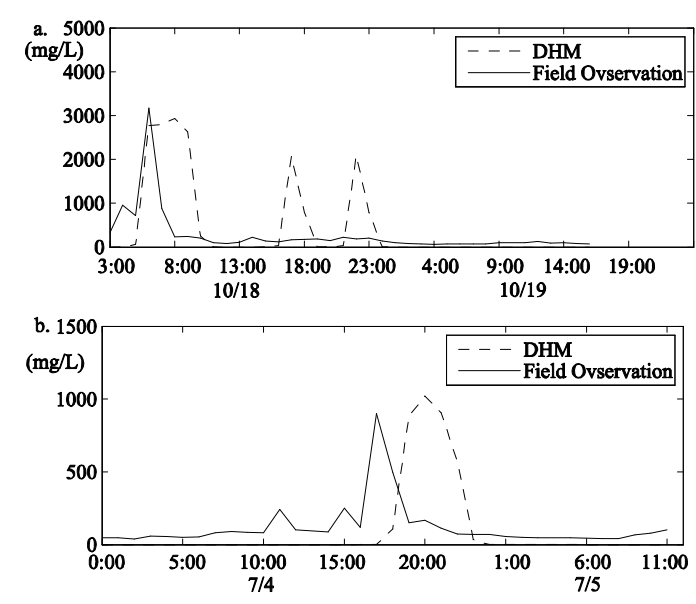

図- 7 オロムシ川下流端でのSS濃度の再現計算結果( 再

現期間：(a) 2009/10/18 3:00 - 10/19 16:00

(b) 2010/7/4 0: $00-7 / 4$ 11: $\infty$ )

1時間程度，2010年7月4日では3時間程度，SS濃度のピー クが遅れて計算されていた . 本研究では, 高濁度の発生 を対象としているためSS濃度は, 斜面からのみ発生する ものとし, 河道内からは発生しないものとして計算を 行った. 即ち, 本研究で行った計算では, 降雨により斜 面で表面流力発生した場合のみ, 降雨に計算されたSS濃 度が表面流とともに斜面から下流入運搬されるものとし て計算されるため, 斜面で表面流力発生していない場合， SS濃度は下流へ運搬されない, 弚のため, 降雨か観測さ れており，表面流力溌生した場合にはSS濃度も発生する と計算されてしまう可能性がある(図-6(a), 図-7(a)) .

本研究の再現計算は, 流域内での雨量観測か実施され ていないため, 最も近傍て観測されていたアメダス観測 点(北見観測所)の降雨データを用いている . 兴のため, 実際の流域に降った雨と違いがあり，このことがS濃度 の再現計算に大きな影響を与えていると考えられる . ま た，本研究での再現計算では，発生するSS濃度は土地利 
用区分による違いは表現するようにモデル化されている が, Ishidaら (2010) ${ }^{6}$ が示した表層土壤の違いによる細粒 土砂の発生特性の違いは表現されていない .

本研究の検討により，土地利用区分を考慮してSS濃度 のピークを再現することが可能であると明らかになった， 今後は, 土地利用区分による降雨とSS濃度のモデル式を 適用するとともに，Ishidaら (2010) ${ }^{6}$ が沶した表層土猿の 違いによる細粒土砂の発生特性の違いを考慮した細粒土 砂流出モデルを構筑することにより，高濁度水の原因と なる細粒土砂の流出をより精度よく再現できるものと考 える。

\section{5 ．まとめ}

本研究で得られた主要な結論を以下に示す。

（1）オロムシ川, 森林地 , 畑地の全てで, 降雨に伴 い, 流出，SS濃度ともによく反応しており，降 雨ピーク時とほぼ同時に流出, SS濃度ともピー クか出現していた。

（2）観測結果から，森林地と畑地の細粒土砂の生 産・流出では，畑地の方か森林地に比へ非常に 細粒土砂が生産・流出し易いことが明らかに なった。

（3）高濁度の発生原因と考えられる細粒土砂の発生 源として，森林地と畑地に着目して観測した結 果から, 森林地と畑地の細粒土砂の生産・流出 は，森林地で5mm程度までSS濃度力増加傾向， 畑地では2mm程度まで急激にSS濃度力増加傾向 にあり，光れ以降はSS濃度が一定の值になる傾 向か確忍された。

（4）森林地と畑地の観測結果により，時間降雨ピ一 クと同時刻のSS濃度の関係から降雨によって発 生するSS濃度の推定式を提案できた。

（5）分布型流出モデルによって，流域の流出を再現 した結果 , ピーク流量は十分な精度で再現する ことか出来た

(6) 提案された降雨によるSS濃度の推定式と流出の 再現性か確認された分布型流出モデルを適用し て, 流域の土地利用区分( 本研究では, 森林地 と畑地)に応じた計算を行うことで，オロムシ 川下流端で観測されたSS濃度のピークを良好に 再現することか出来た .

本研究て超高濁度水の発生場として考えられる森林地 と畑地の現地観測結果により，土地利用区分による細粒 土砂の生産の違いを明らかにし，SS濃度の推定式を提案 した . 今後は，地形特性を考慮した発生寄与率の違いに 着目して検討を行い, 超高濁度の発生のメカニズムを解 明していく予定である .
謝辞 : 本研究を実施するために , 畑地の観測場所を提供 して下さった方，森林地の観測場所を提供していただい た北海道林業試験所の方々のこ協力をいただきました . また, 本研究は, 河川整備基金及び国土交通省による助 成により遂行されました.記して感謝の意を表します。

\section{参考文献}

1) Kline T. C., Goering J.J., Mathisen O. A., Poe P. H. and Parker P. L.: Recycling of elements transported upstream by runs of Pacific salmon: I. delta-15 N and delta-13 C evidence in Sashin Creek, southeastern Alaska, Canadian Journal of Fisheries and Aquatic Sciences, Vol.47, pp.136-144, 1990.

2) 中山恵介, 大西健史, 堀松大志, 早川博, 岡部博一, 溝口 勝巳, 常呂川における平水時の長期的な水質変化について, 土木学会北海道支部論文報告集，第64号，B-24，2008.

3）大澤和敏, 山口悟司, 池田駿介 , 高椋恵, 農地における土 砂流出抑制対策の比較試験, 水工学論文集, 第49巻, pp.1099-1104, 2005.

4) Osawa K, Ikeda S. and Yamaguchi S.: Field observation and WEPP application for sediment yield in an agricultural watershed, River, Coastal and Estuarine Morphodynamics, River, Coastal and Estuarine Morphodynamics, pp.1137-1146, 2005.

5) 石田哲也, 中山恵介, 大西健史, 夏井皓盛, 大森未音, ア イヌルアブリズ, 丸谷靖幸, 岡田知也 : 融雪期における黄 濁土水発生機構と細粒土砂輸送, 水工学論文集, 第54巻, pp.433-438, 2010.

6) Ishida T, Nakayama K, Okada T, Maruya Y, Onishi K. and Omori M.: Suspended sediment transport in a river basin estimated by chemical composition analysis, Hydrological Research Letters, pp.55-59, 2010.

7) V'azquez RF, Feyen L, Feyen J and Refsgaard JC.: Effect of grid size on effective parameters and model performance of the MIKESHE code. Hydrological Processes, Vol.16, Iss.2, pp.355-372, 2002.

8) Alam M. J., Dutta D. and Nakayama K.: A catchment based approach of nutrient modeling in a river basin, the 12th International Conference on Integrated Diffuse Pollution Management (IWADIPCON 2008), 2008.

9) Dutta D. and Nakayama K.: Effects of Spatial Grid Resolution on River Flow and Surface Inundation Simulation by Physically Based Distributed Modeling Approach, Hydrological Processes, Vol.23, Iss.4, pp.534-545, 2009.

10) Alam Md. J., D. Dutta and K. Nakayama: Modeling Nutrient Saru River, Japan, the 7th Eco-Hydraulics, Topics 13 - Solute and Nutrient Transport and Exchange, No.30, pp.1-10, 2009.

11) 中山恵介, 伊藤哲, 藤田睦博, 斉藤大作 : 融雪を考慮した 山地流出モデルに関する研究, 土木学会論文集, No.691/ II57, pp.25-41, 2001. 